\title{
Clarion 4
}

October 25, I86o

Countrymen,

We have talked about the homeland at length in our pamphlets. We did so because the homeland is the dearest thing to those who love it, and it is the most pleasantly coined word adorning the Arabic language. Syria, which is known as Barr alSham and Arabistan, is our homeland with all its diverse plains, coastlines, mountains, and barren lands. The inhabitants of Syria, regardless of their religious beliefs, their physical features, their ethnicities, and their general diversity, are all our compatriots. For the homeland resembles a chain of many rings. One end of the chain represents our place of residence, birthplace, or ancestral home. At the other end lies our country and everyone in it. The center and magnet of these two poles are our heart. The homeland holds strong sway over its children. It draws and holds them within its embrace, however loose this embrace might be. It also captures their hearts and pulls them closer to their homeland so that they may return even when their lives are more comfortable abroad.

"If homelands were not to die for, the ill-fated homelands would turn into ruin." The more we identify with the homeland's material and moral aspects, the more we are attracted to 


\section{Clarion 4 / 77}

it, and the fonder we become of it. ${ }^{1}$ For we deem our house to be the best of houses, our compatriots the best of people. As the saying rightly goes: "Seek the host-not the house." For whoever travels the world sees as clearly as daylight that no matter how meritorious a homeland is, the evils of its people can ruin it. Conversely, no matter how rotten it is in and of itself, the merits of its people compensate for it.

\section{Countrymen,}

People of the homeland have rights vis-à-vis their country which in turn has obligations toward them. It goes without saying that the more these rights are fulfilled, the more people grow attached to their country, and the more desirous and pleased they are in rendering those duties. Among the obligations that a country owes its people is to secure their precious right to life, honor, and prosperity. ${ }^{2}$ These obligations also include upholding civil, moral, and religious freedoms, especially the freedom of conscience in confessional matters. Many were the countries that were sacrificed for this freedom.

Compatriots love their country more whenever they sense that it is theirs. Their happiness lies in its civilizational development and comfort while their misery lies in its destruction and misfortune. Their ability to take part in its affairs and to get involved in its welfare increases their desire for its success and their enthusiasm for its progress. The more responsibility is placed on them, the more intense and resolute these feelings become. Therefore, one of the most important duties of our compatriots is to love their homeland.

It has been mentioned in a hadith: "Love of the homeland is an element of faith."3 Many were the people who sacrificed their 
lives and all that they own out of love for their country. As for those who exchange patriotism for confessional fanaticism and who sacrifice the welfare of the homeland for personal interests, they do not deserve to belong to the homeland. They are its enemies. Those who do not expend any effort to prevent or alleviate incidences harmful to the country are equally its enemies. In these difficult times, few compatriots have displayed their patriotism. The ugly deeds of those who fired the first shot and those who lifted the first stone off the mouth of the dreadful volcano that is torching the country and its people have forever left a black mark in the annals of Syria. Likewise, those who did not work hard to muzzle the barrel of that gun and the mouth of that volcano are guilty; they have fallen short in their duties toward their homeland.

Let us take this opportunity to make clear the feelings of gratitude and welcome toward our brothers who are on the other side of the Atlantic and toward their children who are guests in our country. They have shown and are still showing continuous assistance to our compatriots. Their generosity shames us.

\section{Countrymen,}

Our country is world renowned for its water, air, and soil. It is the most proud and praiseworthy. Yet for a number of generations, it has been afflicted by the corruption of uncivilized segments of its people. That is why you see it increasingly lagging behind other countries and becoming even more backward following the recent unrest. But we hope that with the help of God, with the stamina of our Sublime State and the friendly Great Powers, this current setback, whose echoes have reached the corners of the inhabited Earth, will turn into the beginning of 
great goodness and usher in a new age for Syria. The following may suffice as a reminder for those who are weary:

Tell those who carry a burden: burdens do not last

Happiness dies out; worries become a thing of the past

Countrymen,

We warn you of obstinacy, despotism, fanaticism, and idleness. They are devoid of goodness. And we alert you to these precious words: "Do unto others as you would have them do unto you." We remind you of this as well: Man's true homeland is not in this world but in the spiritual world beyond the grave. There he shall remain till the horn is sounded and he is resurrected for Judgment. Alas, many of our brethren have gone this year to this other, everlasting homeland. Numerous are the causes but death is one. It is therefore incumbent that we prepare for that homeland and the Day of Judgement.

From a patriot 